\title{
INCORPORATION OF CONTINENTAL AND URBAN RUN-OFF INTO A COASTAL CIRCULATION MODEL: APPLICATION TO THE CATALAN COAST
}

\author{
Maria Liste ${ }^{1}$, Manel Grifoll ${ }^{2}$, Ingrid Keupers ${ }^{1}$, Jaak Monbaliu ${ }^{1}$ and Manuel Espino ${ }^{2}$.
}

\begin{abstract}
A 3D hydrodynamical model has been set up to incorporate the continental and urban run-off into the Catalan Coastal waters. Particular attention was paid to introducing correctly the freshwater plumes and attention was also paid to determinate the influence of the land discharge profile with regard to the distributed continental run-off. The model domain includes a small part of the Catalan Coast where the combination of local land topography with torrential rainfall caused considerable local runoff on a short period of time with a large impact on the receiving coastal waters. The Regional Ocean Modeling System (ROMS) simulations were used to examine the dispersal to a freshwater delivery from two relevant event; a low river discharge typical of mean conditions during April 2011 and a high discharge representative of the storm event during March 2011 are considered. We have observed the plume responses to an abrupt change in river discharge. During the mean conditions, low salinity water is concentrated around the rivers mouth while during the flood event, the plume spread offshore in the direction of river water outflow and turned downstream close to the coast. The differences between a simulation including the river outflow as a land forcing and a simulation including river and urban runoff as a land forcing suggested that the urban runoff plays an important role in the spreading and shape of the river plume.
\end{abstract}

Keywords: land boundary fluxes, urban runoff, river discharge, freshwater plume

\section{INTRODUCTION}

Coastal seas are ecologically and economically among the most productive areas of the world ocean and have been the subject of many international agreements and conventions looking to preserve and exploit them in a sustainable manner. Additionally, more than 120 million people live in and "impact" on Europe's coastal regions and their quality of life is affected by the environmental status of its regional seas. Most studies on freshwater influence into the coastal sea have focused on estuarine environments (e.g., Wang et al. 2011; Liu et al. 2009; MacCready et al. 2009; Warner et al. 2005; Hetland R.D., 2004) but continental/urban runoff has been rarely considered in coastal circulation although an adequate incorporation of the land boundary fluxes plays a crucial role for assessment and prediction of circulation in coastal waters.

This paper discusses the implementation of the land boundary fluxes for coastal circulation modeling including river and urban runoff in the Catalan coast. In the classical model of buoyant outflow into coastal oceans, the freshwater discharged into the coastal ocean from rivers and runoff is often observed to be incorporated into a narrow coastal current that is typically a few internal Rossby radii wide and that rapidly transports freshwater downshelf (Garvine 1999). However, more recent theoretical, modeling, and laboratory studies (Avicola and Huq 2003a; Fong and Geyer 2002; Nof and Pichevin 2001) revealed a tendency for the formation of a recirculating bulge structure in the vicinity of the outflow in the absence of wind and alongshore current. Different factors and forcing modify the pathways of the freshwater plume (Zhang et al. 2009): outflow angle (Avicola and Huq 2003a,b; Garvine 1999), wind forcing (Fong and Geyer 2001; Berdeal et al. 2002; Lentz and Chapman 2004; Whitney et al. 2005; Choi and Wilkin 2007; MacCready et al. 2009; Xia et al. 2010; Schiller et al. 2011), ambient current (Fong and Geyer 2002; Berdeal et al. 2002; Hickey et al. 2005), tides, and local topography (Schiller et al. 2011). These factors and forcing modify the pathways of the river plume and can make it similar to the classical theory.

Moreover, the details of freshwater dispersal processes can affect ocean stratification (Garvine and Whitney 2006). In this study we use a numerical model to incorporate the land boundary fluxes into a coastal circulation model in the Catalan coast zone during spring 2011 (from March 1, 2011 to April 31, 2011) in the framework of the Field AC project (www.field_ac.eu).The Catalan Coast was chosen for this study because local (torrential) rainfall is considered to have a high impact on the quality of coastal waters and it is thus important to be able to predict the land discharge adequately such that it can be incorporated into the coastal scale oceanographic models (Keupers et al. 2011). The study area, as many parts of the Mediterranean environment, is under strong anthropogenic pressure and requires in-depth knowledge of the marine environment for appropriate management (Grifoll et al. 2012).

\footnotetext{
${ }^{1}$ Hydraulics Laboratory, KU Leuven, Kasteelpark Arenberg 40, B-3001 Heverlee, Belgium.

${ }^{2}$ LIM/UPC, Jordi Girona, 1-3, 08028, Barcelona, Spain.
} 
The study region is adjacent to a relative narrow shelf. The Catalan shelf widths are between 20 $\mathrm{km}$ in the current study area and $60 \mathrm{~km}$ in the south margin near the Ebro Delta. The shelf break is located at the $200 \mathrm{~m}$ isobath and the averaged slope is of the order of $10^{-2}$. The Catalan Coast under study exhibits micro-tidal fluctuations, freshwater input, air-sea exchange, large-scale shelf circulation, and variable bathymetry all of which influence circulation processes. The coastal circulation is strongly polarized in the along-shelf direction due to the coastal boundary constraint. The along-shelf current fluctuations are basically controlled by wind stress at short time scales and by remote pressure gradients at synoptic time scales (Grifoll et al. 2012).

The goal of this paper is to relate land boundary fluxes to different plume discharges. In particular, this paper will compare the relative importance of different freshwater discharges of the plume and the role of land boundary fluxes in determining the structure of the plume.

The outline of this paper is as follows: section 2 introduces the modelling tools, section 3 shows the verification. In section 4 , the simulated salinity dynamics are presented and discussed. The results are summarized in section 5 .

\section{MODELLING TOOLS}

\section{Coastal Circulation Model}

The ocean model used is the Regional Ocean Modeling System (ROMS), a general class of free surface, terrain-following numerical models that solve the three dimensional Reynolds-averaged Navier-Stokes equations (RANS) using the hydrostatic and Boussinesq approximations (Shchepetkin and McWilliams 2005, 2009; Haidvogel et al. 2008). ROMS uses finite-difference approximations on a horizontal curvilinear Arakawa $\mathrm{C}$ grid and on a vertical stretched terrain-following coordinate. Momentum and scalar advection and diffusive processes are solved using transport equations and an equation of state computes the density field that accounts for temperature, salinity, and suspendedsediment contributions. ROMS provides a flexible structure that allows multiple choices for many of the model components such as several options for advection schemes, turbulence models, lateral boundary conditions, bottom- and surface-boundary layer submodels, air- sea fluxes, surface drifters, a nutrient-phytoplankton-zooplankton model, and an adjoint model for computing model inverses and data assimilation. The code is written in Fortran90 and runs in serial mode on a single processor, or uses either shared- or distributed- memory architectures (OpenMP or MPI) to run on multiple processors (Warner et al. 2010). ROMS is open source and freely available (www.myroms.org).

\section{Model domain and grid}

The Catalan coast is located in the north-western Mediterranean at the latitude $40^{\circ} 45^{\prime} \mathrm{N}$ to $42^{\circ} 25^{\prime}$ $\mathrm{N}$ and longitude $0^{\circ} 45^{\prime} \mathrm{E}$ to $3^{\circ} 15^{\prime} \mathrm{E}$ (Figure 1. Catalan Coast, panel left). This study has used the Coastal grid (Figure 1, right panel). The Coastal grid has 152x207 grid cells, adopts a horizontal grid size of approximately $250 \mathrm{~m}$ (fine enough to capture the relevant coastal details and oceanographic processes) and 20 sigma vertical levels. The Coastal grid is located at the latitude $41.02^{\circ} \mathrm{N}$ to $41.55^{\circ} \mathrm{N}$ and longitude $1.89^{\circ} \mathrm{E}$ to $2.62^{\circ} \mathrm{E}$ (Figure 1. Catalan Coast and coastal grid, right panel).

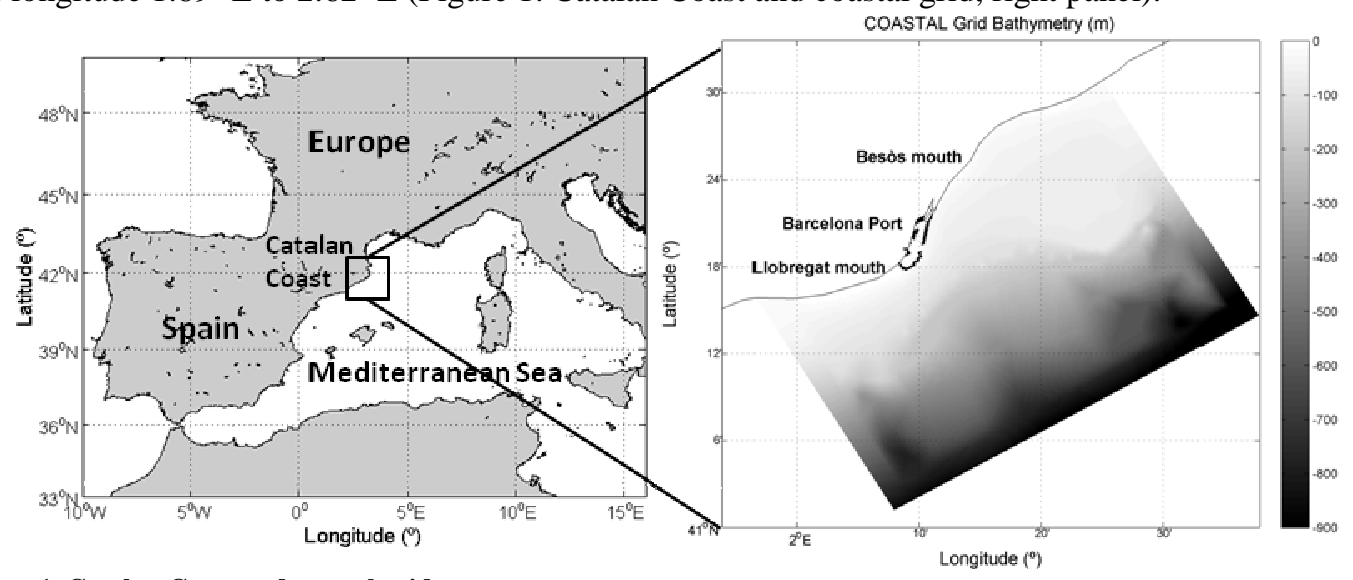

Figure 1. Catalan Coast and coastal grid 


\section{Model Setup}

\section{Initial and boundary conditions}

Model grid

For this work we have used nested increasing-resolution domains in order to introduce the initial and the boundary conditions with enough resolution to reproduce the coastal features. The method is based on structured grid models where there is a spatially large grid that encompasses the entire domain of interest. The Regional domain (which is the same as the MyOcean Mediterranean Sea grid) is large enough to cover the entire domain of interest and has a resolution to adequately resolve basin scale dynamics. We use a grid that covers the entire northwest part of the Mediterranean Coast including the Gulf of Leon and the Balearic Islands on a $2.3 \mathrm{~km}$ scale (Figure 2, left panel). Within the Regional model a region with increased grid resolution has been defined. This model is called SHECAT and the domain covers the Catalan Coast region providing a refined grid on a $1 \mathrm{~km}$ resolution (Figure 2, central panel). Finally, within the SHECAT model another region with increased grid resolution has been defined. This is called the Coastal model and is located offshore of the northeastern districts of Barcelona City area (between a bit north of the Bèsos River mouth and a bit south of the Llobregat River mouth) (Figure 2, right panel).
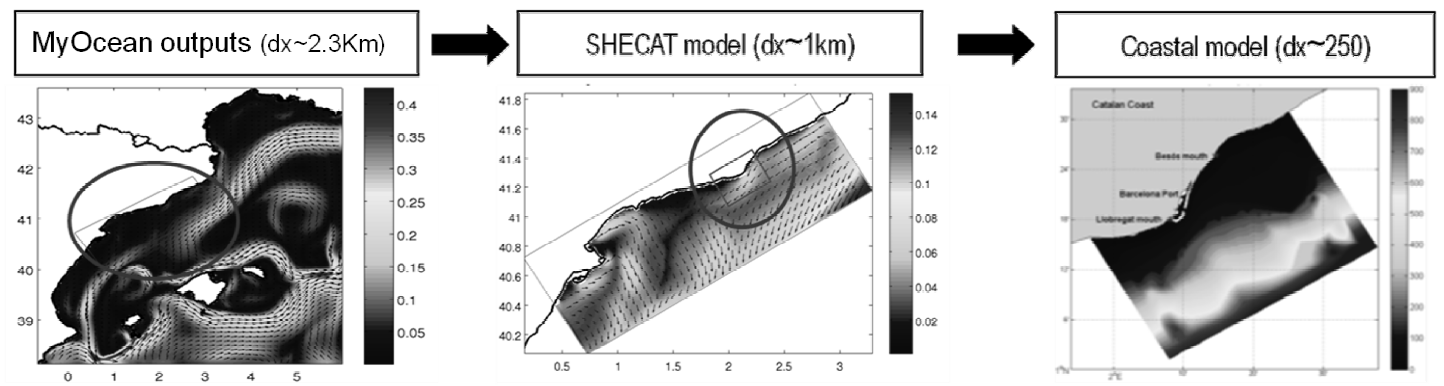

Figure 2. Nested increasing-resolution domains

The one-way nesting is achieved (for the initial conditions, the boundary conditions and the forcing) as follows. The Regional model (MyOcean data) takes one complete baroclinic time step, which includes several barotropic steps. The prognostic variables of the coarse regional model are then interpolated in space to fill boundary arrays for the SHECAT model which in turn provides the boundary arrays for the finer Coastal model. This allows the region of interest to be resolved with an increased spatial resolution and to be driven with forcings that are dynamically consistent because the physics are being resolved on both grids with consistent formulations.

\section{Initial conditions}

Initial conditions for the ocean model fields of currents, depth-averaged currents, water level, salinity, and temperature as well as lateral boundary conditions for currents, salinity, and temperature are obtained from MyOcean products (http://www.myocean.eu/).

\section{Atmospheric forcing}

The rainfall forecast that is used as input to both the river and urban runoff models to calculate the land boundary fluxes is provided by the Barcelona Super Computing Center (BSC). It is generated by the air quality model CALIOPE ( $h t t p: / / w w w . b s c . e s /$ caliope $)$ and provides information on the accumulated rainfall per hour in each grid cell of the domain (European, $1 \mathrm{~km}$ of resolution).

Forcing winds have been generated by the same air quality model CALIOPE and provide information of the wind velocity per hour in each grid cell of the domain.

\section{Land forcing}

The run-off data file that has been used as input file for the coastal model is provided by the conceptual river and urban runoff models that have been calibrated as part of the FIELD_AC project (Keupers et al. 2011). The urban runoff model provides hourly flow time series $\left(\mathrm{m}^{3} / \mathrm{s}\right)$ for the four combined sewer overflows (CSOs) that are situated in the Coastal model (netcdf format). The river runoff model provides hourly flow time series $\left(\mathrm{m}^{3} / \mathrm{s}\right)$ for both the Besòs and the Llobregat river. 


\section{COMPARISONS WITH OBSERVATIONS}

In this section, selected aspects of the simulated results are compared with observations. The bulk of the measurements correspond to a field campaign conducted during March and April 2011 over the Catalan inner-shelf (around Bèsos river mouth, Figure 3, panel left) in the framework of the FIELD_AC project. Several data are available for model comparison (the data set consists of water velocity time-series from three ADCP, wind data (www.pontdelpetroli.org), wave data from buoys (www.xiom.cat) and several CTDs), but in this paper only the comparison of the simulated salinity fields with the salinity measurements from CTD measurements are shown. The measurements of the field campaign are located inside the Coastal grid between latitudes $41^{\circ} 35^{\prime} \mathrm{N}$ to $41^{\circ} 47^{\prime} \mathrm{N}$ and longitudes $2^{\circ} 19^{\prime} \mathrm{E}$ to $2^{\circ} 30^{\prime} \mathrm{E}$ (Figure 3, right panel). On the $17^{\text {th }}$ of March 43 CTD profiles were collected and another 42 CTD profiles were collected on the $11^{\text {th }}$ of April. Besòs River flow data were obtained from a monitoring station upstream of the river mouth (www.aca.cat). The March $17^{\text {th }}$ survey corresponds to "post-rain conditions" associated with a short and intense Besòs river discharge of 50 $\mathrm{m}^{3} \mathrm{~s}^{-1}$ (mean flow conditions are $4 \mathrm{~m}^{3} \mathrm{~s}^{-1}$ ). These "flash-flood" conditions occur during short (duration of hours) and very intense storm events, typical of the Mediterranean climate, in small river mountainous drainage basins (Bourrin et al. 2008). The April 1 $11^{\text {th }}$ measurements correspond to "normal conditions" associated with a normal Bèsos river discharge.

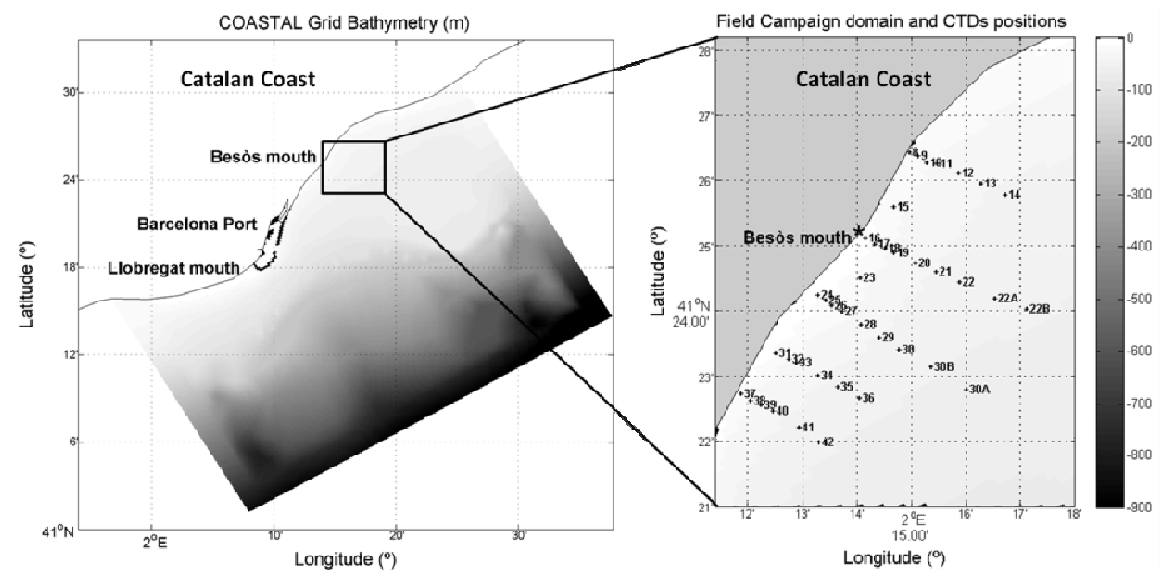

Figure 3. Field Campaign domain and CTDs position located into the Coastal model domain

Modeled surface salinity during the two sampling periods (March $17^{\text {th }}$ and April $10^{\text {th }} 2011$ ) is presented in Figure 4 Error! Reference source not found. The surface salinity exhibits larger spatial variability in March $17^{\text {th }}$ (post-rain conditionsError! Reference source not found., left panel) than in April $11^{\text {th }}$ (normal conditions, Error! Reference source not found., panel right) due to the presence of the signal of Besòs River freshwater. In the normal discharge, low salinity water is concentrated around the rivers mouths. However when a large amount of river water flows into the sea during a flood event, the plume spreaded offshore in the direction of river water outflow and then turned downstream close to the coast. More detailed analysis indicated that the water exchange rate between the water around the river mouth and the outside area was proportional to the river discharge.
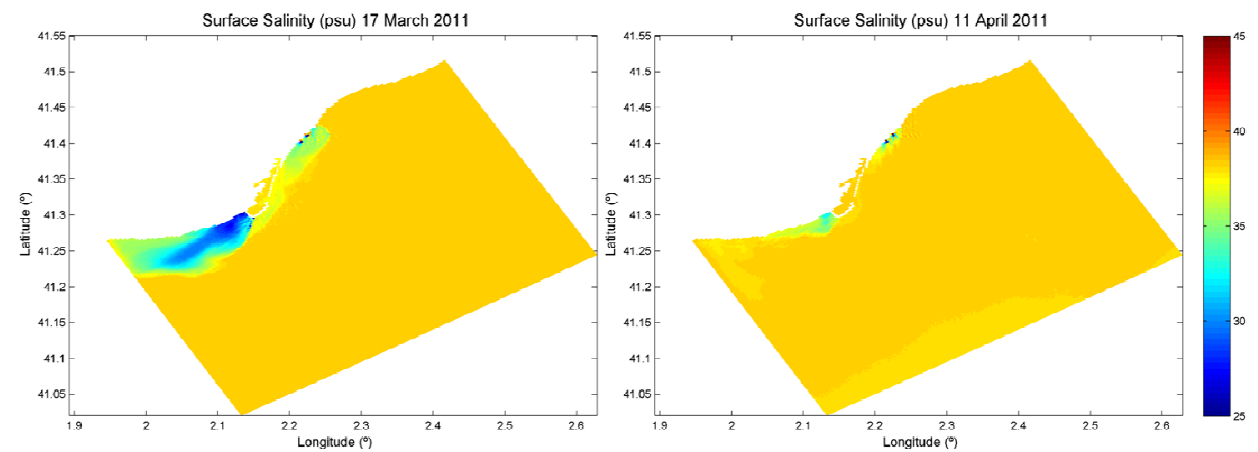

Figure 4. Modeled surface salinity during March $17^{\text {th }}$ (left panel) and April $10^{\text {th }} 2011$ (right panel) 
Figure 5 shows two examples of the salinity profiles from campaign measurements versus the salinity profiles from ROMS results in the same location (profile 33 and profile 41, indicated by stars in Figure 5, left panel). The water column is stratified in both surveys and the plume signal is constrained to the first meters of the water column. During the normal conditions (April 1 $11^{\text {th }}$ 2011), the influence of the plume is small and localized at the first meters of depth (5-15 meters), resulting in fairly constant horizontal salinity structure. ROMS profile result from the same date (April 11 ${ }^{\text {th }} 2011$ ) shows the same pattern than the profile from the campaign, but the values of salinity are overestimated up to 0.5 psu (Figure 5, top-right and bottom-right panel). The post-rain conditions (March 17 $7^{\text {th }} 2011$ ) also present a stratified profile with maximum values between 0 and 8 meters depth. The shape of the ROMS profile follows the same pattern but the salinity values are overestimated up to 2 psu.

A downward transport of freshwater through vertical mixing was evident during the observation period. The difference between the offshore spreading distance of the plume predicted by ROMS, and that observed during field campaigns suggests that the inclusion of vertical mixing and the temporal variation in river discharge should be studied in more detail in future theoretical studies.
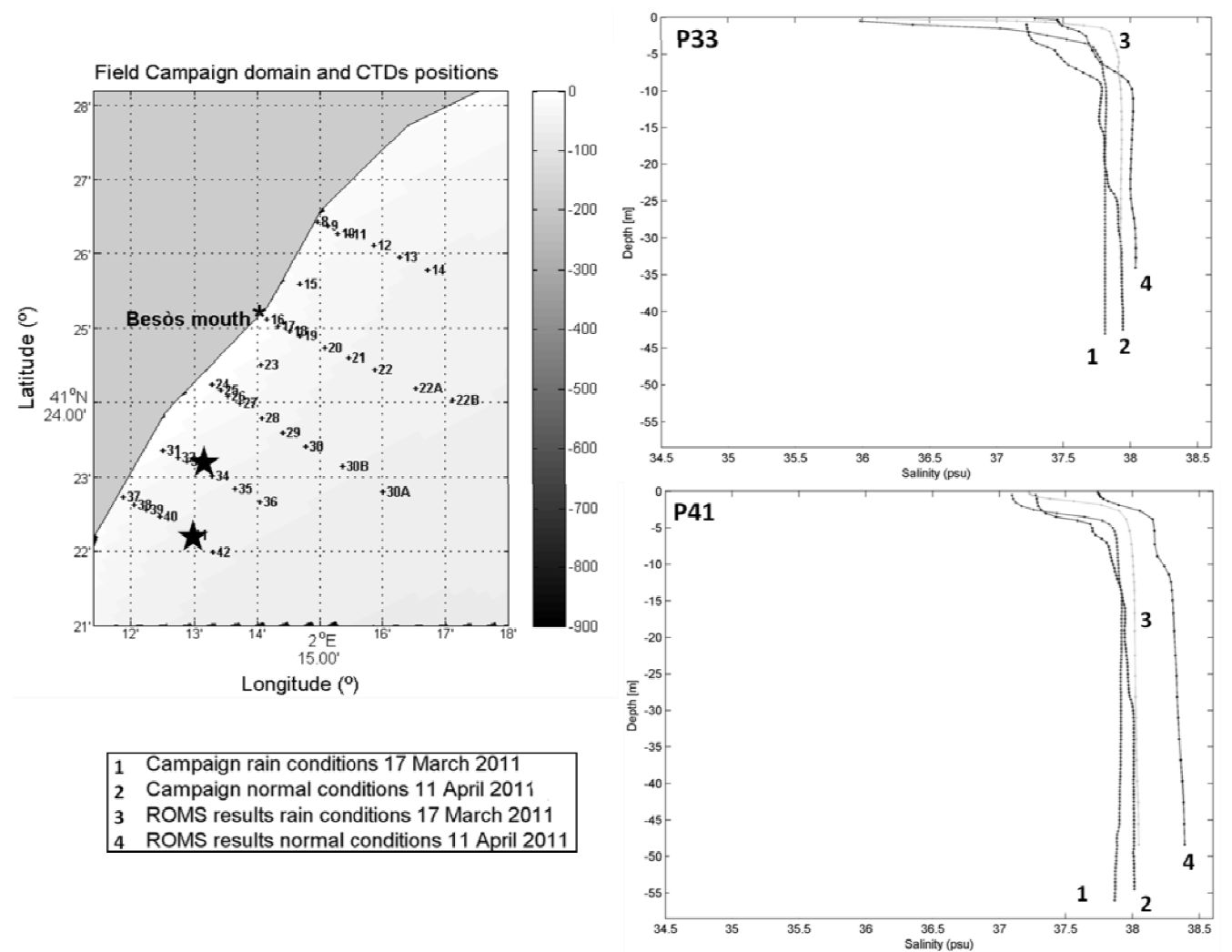

Figure 5. CTD profiles locations during field campaigns (left panel); measured CTD profiles versus ROMS results profiles (right panels).

\section{ANALISYS AND DISCUSSION}

The system was run in 2 configurations, low land boundary fluxes and high land boundary fluxes conditions. For the river flow both the Bèsos River and the Llobregat River are considered. For the urban runoff, the four CSOs namely Ginebra, Bogatell, Bac de Roda and Prim (Figure 6) are taken into account. 


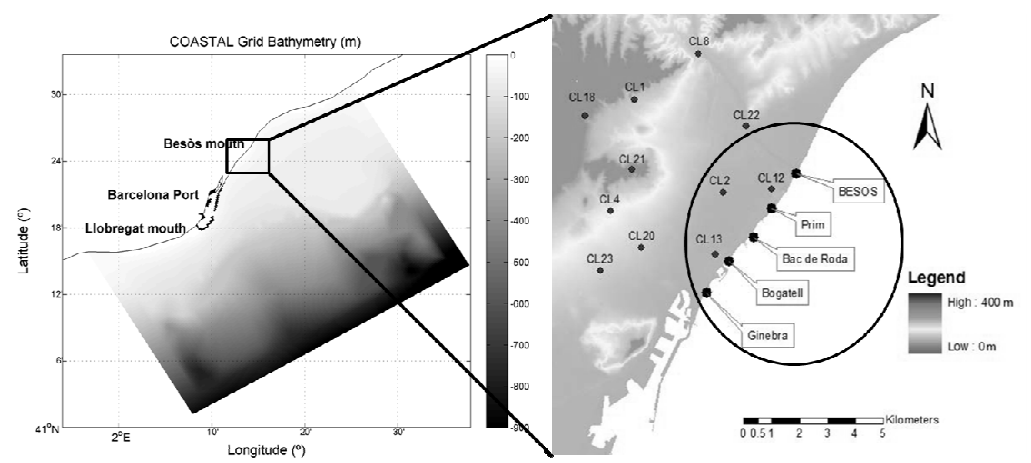

Figure 6. CSOs positions.

The results from a simulation during the flood event (March $11^{\text {th }}$ ) only including river outflow as a land forcing is shown in Figure 7, left panel. The model result including river and urban runoff as a land forcing are shown in Figure 7, right panel. During the flood event the low salinity water is concentrated around the rivers mouths, This values of the salinity are lower in the simulation with river and urban as land forcing. Although the plume spread offshore in the direction of river water outflow and turned downstream close to the coast.
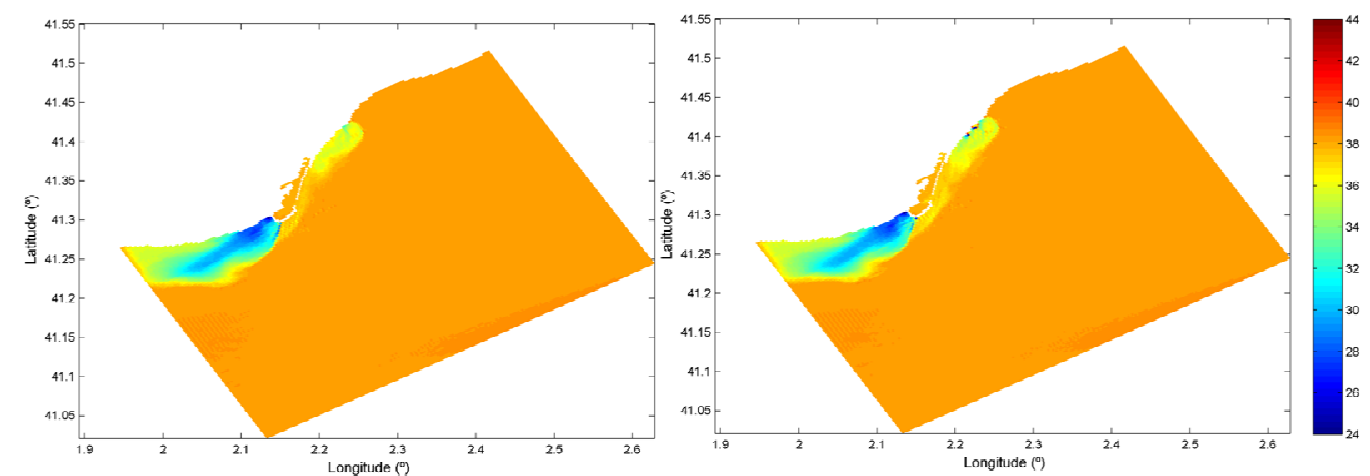

Figure 7. Surface salinity ROMS results (psu). Simulation result during flood event (March $11^{\text {th }}$ ) including river (left panel) and including rivers and urban runoff as a forcing (right panel).

Figure 8., shows the difference in salinity between results from a simulation including the river outflow only as a land forcing (Figure 7, right panel), and the result including river and urban runoff (Figure 7, right panel). This difference suggests that including the urban outflow can play an important role in the spreading and shape of the river plume.

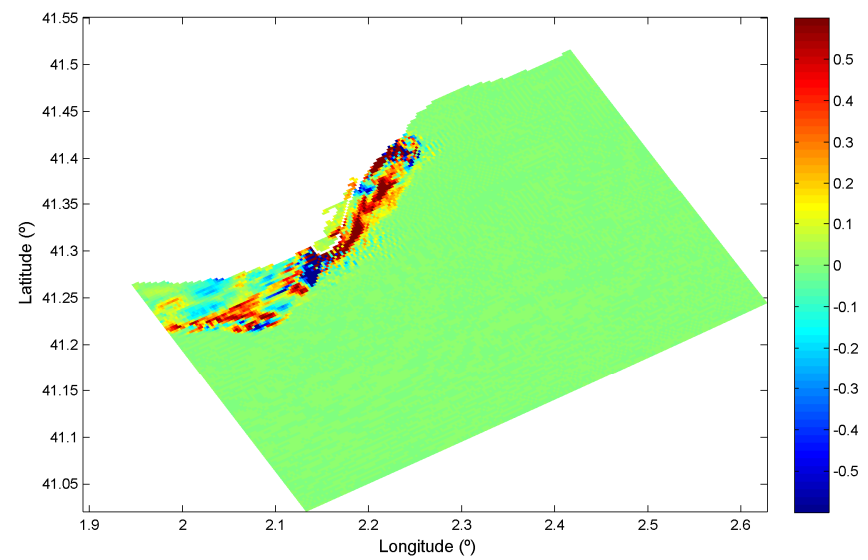

Figure 8. Salinity differences (psu) between the result including the river outflow and the result including river and urban runoff as a land forcing. 


\section{SUMMARY AND CONCLUSION}

Numerical simulations of Catalan Coastal waters in spring 2011 have been conducted using a ROMS model driven by realistic atmospheric and land forcing. The model results were compared with CTD observations. The shape of the salinity profile was well reproduced but salinity values were overestimated. In the two field surveys carried out at the Catalan coast during the spring of 2011 before and during a flood event and during a normal discharge, the response of a plume to an abrupt change in river discharge was observed. The distribution of low salinity water was different between both discharges. In the normal discharge, low salinity water is concentrated around of the rivers mouths. As a large amount of river flood into the sea during the flood event, the plume spread offshore in the direction of river water outflow and turned downstream close to the coast.

Analysis of the results indicated that the water exchange rate between the water around the river mouth and the outside area was proportional to the river discharge. A downward transport of freshwater through vertical mixing was evident during the observation period. The difference between the offshore spreading distance of the plume from ROMS model results and that observed in the field campaigns suggests that the inclusion of vertical mixing and the temporal variation in the river discharge needs to be investigated further in future theoretical studies.

The difference between the simulation including the river outflow as a land forcing and the simulation including river and urban runoff as a land forcing suggests that urban runoff plays an important role in the spreading and shape of the river plume.

This paper provides a first interpretation the role of land boundary fluxes in determining the structure of the plume in the Catalan Sea and is limited to the period of observation (spring 2011). Further work should focus more on the effect of the river discharge annual cycle on the vertical flow structure.

\section{ACKNOWLEDGMENTS}

The work described in this paper was supported by the European Community's Seventh Framework Program through the grant to the budget of the Collaborative Project FIELD_AC, Contract FP7-SPACE-2009-1-242284.

\section{REFERENCES}

Avicola, G., and P. Huq . (2003a). The characteristics of the recirculating bulge region in coastal buoyant outflows. J. Mar. Res, 61, 435-463.

Avicola, G., and P. Huq. (2003b). The role of outflow geometry in the formation of the recirculating bulge region in coastal buoyant outflows. J. Mar. Res, 61, 411-434.

Bourrin, F., P. L. Friend, C. L. Amos, E. Manca, C. Ulses, A. Palanques, and X. Durrieu de._(2008). Sediment dispersal from a typical Mediterranean flood: The Têt River, Gulf of Lions. Continental Shelf Research, 28(15), 1895-1910.

Choi B.J. and J.L. Wilkin. (2007). The Effect of Wind on the Dispersal of the Hudson River Plume. Journal of Physical Oceanography, 37, 1878-1897.

Fong D. A., and W.R. Geyer. (2001). Response of a river plume during an upwelling favorable wind event. J. Geophys. Res, 106, 1067-1084.

Fong, D., and W. Geyer. (2002). The alongshore transport of freshwater in a surface-trapped river plume. J. Phys. Oceanogr, 32, 957-972.

Berdeal I.G., B. Hickey, and M. Kawase. (2002). Influence of wind stress and ambient flow on a high discharge river plume. J. Geophys. Res, 107(C9), 3130.

Garvine R. (1999). Penetration of buoyant coastal discharge onto the continental shelf: A numerical model experiment. J. Phys. Oceanogr, 29, 1892-1909.

Garvine, R.W., and M.M. Whitney. (2006). An estuarine box model of freshwater delivery to the coastal ocean for use in climate models. J. Mar. Res, 64, 173-194.

Grifoll M., A.L. Aretxabaleta, M. Espino, and J.C. Warner. (2012). Along-Shelf current variability on the catalan inner-shelf (NW Mediterranean). Journal of Geophysical Research, 117. In press. 
Haidvogel, D.B., H.G. Arango, W.P Budgell, B.D. Cornuelle, E. Curchitser, E. DiLorenzo, K. Fennel, W.R. Geyer, A.J. Hermann, L. Lanerolle, J. Levin, J.C. McWilliams, A.J. Miller, A.M. Moore, T.M. Powell, Shchepetkin, Sherwood, Signell, Warner and Wilkin. (2008). Regional ocean forecasting in terrain-following coordinates: model formulation and skill assessment . Journal of Computational Physics, 227, 3595-3624.

Hickey B., S. Geier, N. Kachel, and A. MacFadyen. (2005). A bi-directional river plume: The Columbia in summer. Continental Shelf Research, 25, 1631-1656.

Keupers, I., P. Willems, J. Fernandez Sainz, L. Bricheno, J. Wolf, J. Polton, J. Howarth, S. Carniel, and J. Staneva. (2011). Methodology (including best practice guidelines) on how to identify and incorporate 'concentrated' and 'distributed' run-off in pre-operational forecasts, based on the input and requirements from our users. FIELD_AC project, D3.1 90 pp.

Lentz, S. J., and D.C. Chapman. (2004). The Importance of Nonlinear Cross-Shelf Momentum Flux during Wind-Driven Coastal Upwelling. Journal of Physical Oceanography, 34 (11), 24442457.

Liu Y., P. MacCready, B.M. Hickey, E.P. Dever. (2009). Evaluation of a coastal ocean circulation model for the Columbia River plume in summer 2004. Journal of Geophysical Research, 114, C00B04.

MacCready P., S. Banas Neil, B.M. Hickey, E.P. Dever, and Y. Liu. (2009). A model study of tide-and wind-induced mixing in the Columbia River. Continental Shelf Research, 29, 278-291.

Nof, D., and T. Pichevin. (2001). The ballooning of outflows. J. Phys. Oceanogr, 31, 3045-3058.

Schiller R.V., V.H. Kourafalou, P. Hogan, and N.D. Walker. (2011). The dynamics of the Mississippi River plume: Impact of topography, wind and offshore forcing on the fate of plume waters. Journal of Geophysical Research, 116, C06029.

Shchepetkin J.C., and A.F. McWilliams. (2005). The Regional Ocean Modeling System (ROMS): A split-explicit, free-surface, topography-following coordinates ocean model. Ocean Modelling, 9, 347-404.

Shchepetkin, A.F., and J.C. McWilliams. (2009). Correction and commentary for "Ocean forecasting in terrain-following coordinates: Formulation and skill assessment of the regional ocean modeling system" by Haidvogel et al., J. Comp. Phys. Journal of Computational Physics, 228, 3595-3624.

Wang Y., Z. Liu, H. Gao, L. Ju, and X. Guo. (2011). Response of salinity distribution around theYellow River mouth to abrupt changes in river discharge. Continental Shelf Research, 31, 685-694.

Warner J.C., W.R. Geyer, and J.A. Lerczak. (2005). Numerical modeling of an estuary: A comprehensive skill assessment 2005 Journal of Geophysical Research. Journal of Geophysical Research, 110, C05001.

Whitney M.M. and R.W. Garvine. (2005). Wind influence on a coastal buoyant outflow. Journal of Geophysical Research, 110, C03014.

Xia M., L. Xie, and L.J. Pietrafesa._(2010). Winds and the orientation of a coastal plane estuary plume. Geophysical Research Letters, 37, L19601.

Zhang W.G., J.L. Wilkin, and R.J. Chant. (2009). Modeling the Pathways and Mean Dynamics of River Plume Dispersal in the New York Bight. Journal of Physical Oceanography, 39, 11671183. 